\title{
APLIKASI MODEL KEPERAWATAN COMFORT KOLCABA DALAM ASUHAN KEPERAWATAN PADA ANAK DENGAN KERUSAKAN INTEGRITAS KULIT
}

\author{
Lina Mahayaty* \\ *STIKes William Booth Surabaya, Jl.Cimanuk no.20 Surabaya. \\ E-mail:lina_mswb@yahoo.com
}

\begin{abstract}
ABSTRAK
Diaper dermatitis sering terjadi pada anak anak yang berisiko menimbulkan rasa gatal, nyeri, dan ketidaknyamanan. Pendekatan keperawatan untuk memberikan kenyamanan pada pasien didasarkan pada teori Comfort Kolcaba. Teori ini membahas tentang kenyamanan dalam empat konteks kenyamanan yaitu: fisik, psikospiritual, sosial budaya, dan lingkungan, Perianal care dengan menggunakan air merupakan salah satu Evidence Based Nursing Practice yang dapat diterapkan untuk mencegah dan mengatasi diaper dermatitis sehingga kenyamanan pasien dapat teratasi. Hasil dari penerapan teori ini dilakukan pada anak dengan kerusakan integritas kulit. Teori Kenyamanan Kolcaba dapat meningkatkan kesehatan pasien, kepuasan pasien dan keluarga terhadap pelayanan keperawatan bertambah.
\end{abstract}

Kata Kunci: Kerusakan integritas kulit, perianal care, teori comfort Kolcaba

\begin{abstract}
Diaper dermatitis is common in children who are at risk of itching, pain. This leads to discomfort in children. The nursing approach to comforting patients is based on Comfort Kolcaba's (2003) theory. This theory discusses comfort in four comfort contexts: physical, psychospiritual, socio-cultural, and environmental. Perianal care is one of the Evidence Based Nursing Practice that can be applied to prevent and treat diaper dermatitis so that patient comfort can be overcome. The result of the application of this Theory can be applied to children with skin integrity damage. The implementation of Kolcaba Comfort Theory can improve patient health, patient and family satisfaction on nursing services will increase.
\end{abstract}

Keywords: Impaired skin integrity, Kolcaba comfort theory, perianal care. 


\section{Pendahuluan}

Kulit memiliki beberapa fungsi penting bagi tubuh. Sebagai fungsi perspektif fisiologis, kulit akan menjadi barrier tubuh, yang melindungi tubuh terhadap infeksi mikroorganisme dan mempertahankan fungsi metabolik degan mengeksresikan zat sisa (Potts \& Mandleco, 2012). Kulit yang normal (terjaga integritasnya) sangat dibutuhkan agar kulit mampu menjalankan fungsinya, sehingga keutuhan kulit dapat terjaga (Kozier, Erb, Berman, \& Snyder, 2010). Kerusakan integritas kulit atau terganggunya keutuhan kulit merupakan salah satu masalah keperawatan yang dialami anak yang menderita diare. Kerusakan integritas kulit ini terjadi akibat frekuensi buang air besar (BAB) yang berlebihan, sehingga area kulit sekitar perianal sering terpapar feses, akibatnya kulit mudah mengalami kemerahan dan iritasi (Marcdante et al, 2010).

Diare merupakan salah satu faktor yang terkait terhadap kejadian diaper dermatitis. Kelembaban berkepanjangan karena frekuensi penggantian popok yang jarang, dan kurangnya barrier kulit juda dapat memengaruhi terjadinya diaper dermatitis (Buckley, Mantaring, Dofitas, Lapitan, \& Monteagudo, 2016). Diaper dermatitis atau ruam popok merupakan gangguan yang umum terjadi pada kulit bayi dan anak yang berusia 13 tahun (Hockenberry \& Wilson, 2013). Komplikasi dari diaper dermatitis jarang terjadi karena kondisinya mudah diatasi dengan perawatan kulit yang baik, barrier kulit dan pengobatan infeksi yang mendasarinya. Walaupun demikian, jika diaper dermatitis tidak diobati, dapat terjadi komplikasi yaitu meningkatnya rasa nyeri, tingkat keparahan kerusakan kulit, infeksi bakteri, jamur (Shin, 2014), dan terjadinya Jacquet's erosive dermatitis (Ravanfar, Wallace \& Pace, 2012). Melakukan pengkajian pada area perianal untuk melihat kejadian diaper dermatitis sangat perlu dilakukan untuk melakukan tindakan pencehan dan penatalaksanaan. Penilaian skor diaper dermatitis dapat menggunakan Scoring System for Diaper Dermatitis Scale (SSDDS) (Buckley, Mantaring, Dofitas, Lapitan, dan Monteagudo (2016).

Pemberian asuhan keperawatan pada anak yang berpusat pada keluarga (family-centered care) dan yang tidak menimbulkan trauma (atraumatic care) merupakan filosofi dalam keperawatan anak. Asuhan keperawatan yang berpusat pada keluarga terdapat dua konsep dasar yaitu memampukan dan memberdayakan keluarga. Sedangkan dalam perawatan yang tidak menimbulkan trauma bertujuan untuk tidak melukai anak. Tujuan ini dapat dicapai dengan tiga prinsip yaitu: mencegah dan meminimalkan pemisahan anak dari keluarga, meningkatkan rasa kendali, dan mencegah atau meminimalkan nyeri dan cedera pada tubuh (Hockenbery \& Wilson, 2013).

Teori Kenyamanan Kolcaba yang berkaitan dengan kebutuhan pasien akan kenyamanan dapat diaplikasikan pada asuhan keperawatan pasien yang mengalami kerusakan integritas kulit. Tercapai kenyamanan pasien maka peluang anak untuk memulihkan kesehatan dapat ditingkatkan (Kolcaba \& DiMarco, 2005). Kenyamanan adalah suatu keadaan yang mendesak dan diperkuat melalui kebutuhan manusia yang dimiliki untuk relief, ease, dan transcendence yang ditujukan pada empat konteks kenyamanan (fisik, psikospiritual, sosiokultural, dan lingkungan) (Kolcaba \& DiMarco, 2005).

Anak dengan diare yang mengalami kerusakan integritas kulit akan mengalami ketidaknyaman dalam konteks fisik karena keutuhan jaringan kulit telah mengalami kerusakan. Dibutuhkan tindakan untuk meningkatkan kenyamanan melalui intervensi keperawatan yang tediri dari tiga kategori yaitu: (a) standard for 
comfort, untuk menjaga dan mencegah terjadinya kerusakan integritas kulit melalui perianal care; (b) coaching, untuk mengurangi kecemasan, memberikan jaminan informasi, menumbuhkan harapan, mendengarkan dan membantu rencana pemulihan dan (c) comfort food for the soul, yaitu halhal tambahan yang lebih baik yang dapat dilakukan oleh perawat untuk anak-anak dan keluarga merasa diperhatikan dan dikuatkan.

\section{Metode}

Metode pada laporan kasus ini menggunakan pendekatan studi kasus pada tiga kasus kelolaan yang dilakukan di ruang anak salah satu RS Umum dengan pendekatan teori Kenyamanan Kolcaba yang dimulai dengan pengkajian, perumusan diagnosis keperawatan, intervensi keperawatan dan evaluasi. Dalam Teori Kenyamanan Kolcaba, pengkajim dinilai berdasarkan konsep spesifik yang disusun dalam tiga bentuk dan empat konteks kenyamanan. Tiga jenis kenyamanan adalah relief, ease, dan transcendence. Pasien mengalami rasa nyaman saat kebutuhan kenyamanan individu terpenuhi, atau berada pada jenis transcendence. Empat konteks kenyaman yang dikaji adalah kenyamanan fisik, psikospiritual, lingkungan, dan sosial budaya. Kenyamanan fisik dikaji berdasarkan sensasi tubuh dan mekanisme homeostatik, psikososial berkaitan dengan kesadaran internal diri, lingkungan adalah lingkungan dan kondisi eksternal, dan sosiokultural mengacu pada hubungan interpersonal dan sosial (Kolcaba \& Fisher, 1996 dalam Krinsky, Murillo, \& Johnson, 2014). Kasus yang diambil merupakan anak dengan masalah kerusakan integritas kulit dengan intervensi keperawatan perianal care untuk melihat kejadian diaper dermatitis.

\section{Hasil}

Dalam karya ilmiah ini akan digambarkan sebanyak tiga pasien kelolaan yang mengalami dan berisiko mengalami kerusakan integritas kulit yang dikelola. Kelima pasien kelolaan akan dipaparkan sebagai berikut:

\section{Kasus 1}

Bayi Ny.D.S laki-laki berusia 7 bulan, masuk ruang infeksi terdiagnosis medis diare akut dehidrasi ringan sedang dan atresia billier. Pasien masuk IGD melalui polikinik gastroenterologi dengan keluhan buang air besar (BAB) berdarah 4 hari sebelum masuk rumah sakit, bab berwarna kuning, cair, ada lendir dan darah. Di IGD anak diberikan antibiotik, koreksi albumin, dan diberikan Vitamin K.

Hasil pengkajian aspek fisik pada didapatkan data pasien berada pada relief yaitu: Mukosa mulut kering, turgor kulit tidak elastis, abdomen ascites, hepar teraba $3 \mathrm{~cm}$ dibawah px, sklera ikterik, buang air besar $5 \mathrm{x} / \mathrm{hari}$, konsistensi cair, warna feses kuning, membran mukosa kering, warna kulit tampak kuning, tampak kemerahan pada perianal, Scoring System For Diaper Dermatitis Scale (SSDDS) yang memiliki skor 0-6, pasien berada pada skor 3 pasien mengalami keterlambatan perkembangan, skala nyeri : Face, Legs, Activity, Cry, Consolability (FLACC) skor 2, terpasang Nasogastric Tube (NGT) untuk pemenuhan nutrisi. Pemeriksaan laboratorium didapatkan hasil: Albumin 2, 96, analisis tinja (terdapat leukosit: 4-6/LPB, eritrosit: 10-12/LPB dan darah samar tinja: Positif). Aspek psikospiritual ditemukan anak mengalami ease ditunjukkan dengan pasien tampak tenang. Aspek sosialkultural dan aspek lingkungan berada pada transcendence. Berdasarkan hasil pengkajian didapatkan diagnosis keperawatan yang muncul adalah 1) kekurangan volume cairan, 2) ketidakseimbangan nutrisi, 3) diare, 4) kerusakan integritas kulit, 5) nyeri, dan 6) risiko keterlambatan perkembangan.

Intervensi yang dilakukan mengacu pada tiga kategori. Intervensi keperawatan 
berdasarkan 1) Standard of comfort yaitu: Kaji status hidrasi, monitor tanda vital, kesadaran, timbang berat badan, pertahankan keakuratan asupan dan haluaran, berikan asupan nutrisi sesuai kebutuhan, pantau status nutrisi, pola buang air besar, kondisi kulit, skala nyeri, dan kolaborasi pemberian antibiotik dan inhalasi. 2) Coaching yaitu: Ajarkan keluarga membersihkan area perianal, stimulasi pada anak, anjurkan keluarga untuk mencatat setiap haluran, jelaskan pentingnya nutrisi yang adekuat untuk anak, ajarkan pemberian makanan melalui NGT, luangkan waktu mendengarkan keluhan anak. 3) Comfort food for the soul yaitu: Berikan posisi yang nyaman, ciptakan lingkungan yang bersih, nyaman dan tenang, anjurkan orangtua untuk menghubungi perawat jika membutuhkan sesuatu.

Evaluasi dilakukan pada perawatan hari ketiga yaitu: 1) Fisik, relief, dengan uraian: turgor kulit tidak elastis, kulit perianal masih tampak kemerahan, SSDDS Skor 3, skala nyeri FLACC 2. Intervensi dilanjutkan oleh perawat ruangan dan pasien diijinkan pulang pada hari Senin, 19 Februari 2017.

\section{Kasus 2}

Bayi A.F laki-laki berusia 8 bulan, masuk ruang infeksi dengan diagnosis medis diare akut dehidrasi ringan sedang dan morbili. Ibu pasien mengeluh anaknya mengalami demam naik turun sejak 4 hari sebelum masuk rumah sakit, batuk, tidak mau makan, dan sulit tidur malam hari, diare 8 kali selama di rumah, bintik-bintik merah sejak 2 hari yang, muncul pertama kali pada area dada, meluas sampai bagian perut dan wajah. Di IGD RSCM Bayi A.F dilakukan pemasangan infus Kaen 3B $15 \mathrm{ml} / \mathrm{jam}$.

Hasil pengkajian pada aspek fisik didapatkan data pasien berada pada relief yaitu: Pasien rewel, fontanella anterior cekung, kelopak mata cekung, mukosa mulut kering, turgor kulit tidak elastis, rash pada seluruh tubuh, badan anak teraba panas, batuk, terpasang NGT untuk pemenuhan nutrisi, status gizi buruk, hanya menghabiskan $1 / 4$ porsi dari makanan yang disediakan, terdengar ronchi pada seluruh lapang paru, batuk, SSDDS skor 5 , suhu $38^{\circ} \mathrm{C}$, FLACC skor 4. Aspek psikospiritual ditemukan tipe kenyamanan anak relief dimana anak tampak rewel. Aspek sosialkultural pada ease yaitu: Pasien di rawat di ruang isolasi. Aspek lingkungan, pada relief, ibu pasien mengatakan lingkungan kamar bersih tetapi panas, dan merasa sendiri. Ibu pasien bertanya kapan dapat pindah ke ruangan yang lebih nyaman dan tidak sendiri. Berdasarkan hasil pengkajian didapatkan diagnosis keperawatan yang muncul adalah 1) kekurangan volume, 2) bersihan jalan nafas tidak efektif, 3) ketidakseimbangan nutrisi, 4) hipertermia, 5) nyeri, dan 6) kerusakan integritas kulit.

Intervensi keperawatan berdasarkan 1) standard of comfort yaitu: kaji status hidrasi pasien, kesadaran pasien, skala nyeri, frekuensi dan kedalaman pernapasan, bunyi dan suara napas, status nutrisi, pantau kondisi kulit, timbang berat badan, pantau pemberian cairan, pertahankan keakuratan asupan dan haluaran, berikan asupan nutrisi sesuai kebutuhan, monitor tanda vital, dan kolaborasi pemberian antibiotik dan inhalasi. 2) Coaching yaitu: Ajarkan keluarga membersihkan area perianal, anjurkan keluarga untuk mencatat setiap haluaran, jelaskan pentingnya nutrisi yang adekuat untuk anak, ajarkan pemberian makanan melalui NGT, luangkan waktu untuk mendengarkan keluhan anak. 3) Comfort food for the soul: Berikan posisi yang nyaman, ciptakan lingkungan yang bersih, nyaman dan tenang, panggil anak dengan namanya, anjurkan orangtua untuk menghubungi perawat jika membutuhkan sesuatu.

Evaluasi dilakukan pada perawatan hari ketiga. Pasien diijinkan pulang dengan 
evaluasi keperawatan yaitu: 1) Fisik, relief, dengan uraian: turgor kulit tidak elastis, conjungtiva anemis, masih terdengar suara ronchi pada seluruh lapang paru, skala nyeri FLACC 4, area perianal tampak kemerahan, SSDDS Skor 4. 2) Aspek psikospiritual, ease dengan uraian: Ibu menyatakan merasa tenang karena kondisi anaknya membaik. 3) Aspek Lingkungan, ease, dengan uraian: Ibu merasa nyaman dengan lingkungan perawatan, walaupun ruangan panas.

\section{Kasus 3}

Bayi E.D perempuan usia 11 bulan, masuk ruang infeksi dengan diagnosis medis pneumonia dan HIV-AIDS. Pasien sudah dilakukan pemeriksaan viral load. Pasien menderita tuberculosis dan alergi terhadap susu sapi. Pasien menyelesaikan terapi Obat Anti Tuberculosis (OAT) selama 6 bulan namun terputus putus karena terdapat gangguan fungsi hati. Selama pengobatan di RS sebelumnya juga sudah mendapatkan terapi obat antiretroviral (ARV), namun dihentikan kaerna gangguan fungsi hati. Pasien disarankan rujuk ke RSCM. Saat pasien kontrol anak demam sudah lima hari, sesak dan intake kurang. Ibu pasien mengatakan 5 hari sebelum masuk rumah sakit anaknya mengalami demam tinggi samapi $39^{\circ} \mathrm{C}$, buang air besar $3-$ $5 \mathrm{kali} / \mathrm{hari}$, pasien juga sesak napas.

Hasil pengkajian pada aspek konteks fisik didapatkan data pasien berada pada relief yaitu: Frekuensi pernafasan 56 $\mathrm{x} / \mathrm{mnt}$, suhu $38{ }^{\circ} \mathrm{C}$, berat badan $5,8 \mathrm{~kg}$, panjang badan $63 \mathrm{~cm}$, status gizi: gizi kurang, FLACC scale 2, conjungtiva anemis, diare 5-6 x/hari, konsistensi cair, warna feses hijau, turgor kulit tidak elastis, membran mukosa kering, batuk, ronchi pada seluruh lapang paru, tampak kemerahan pada genetalia, SSDDS skor 2, pasien mengalami keterlambatan. Pada pemeriksaan laboratorium $\mathrm{Hb} 8,51$ g/dl, Ht 25,3\%, Leukosit: 8,66 10\%/ul. Analisis tinja ditemukan, tinja berwarna hijau, terdapat lendir dan eritrosit pada feses. Berdasarkan hasil pengkajian didapatkan diagnosis keperawatan yang muncul adalah 1) bersihan jalan nafas tidak efektif, 2) ketidakseimbangan nutrisi, 3) diare, 4) hipertermia, 5) risiko kekurangan volume cairan, 6) nyeri, 7) kerusakan integritas kulit, 8) risiko keterlambatan.

Intervensi yang dilakukan mengacu pada tiga kategori. Intervensi keperawatan berdasarkan 1) standard of comfort yaitu: Kaji status hidrasi, kesadaran, skala nyeri, frekuensi dan kedalaman pernapasan, bunyi dan suara nafas, pola buang air besar, turgor kulit dan kondisi kulit, timbang berat badan, pantau status nutrisi, pertahankan keakuratan asupan dan haluaran, dan kolaborasi pemberian terapi dan inhalasi. 2) Coaching ajarkan keluarga cara membersihkan area perianal, perkembangan sesuai usia anak, pentingnya nutrisi yang adekuat bagi anak, pemberian makanan melalui NGT, anjurkan keluarga untuk mencatat warna, jumlah, frekuensi dan konsistensi feses, menjaga seprai dan pakaian tetap kering, luangkan waktu untuk mendengarkan keluhan anak, berikan kesempatan kepada orangtua untuk bertanya. 3) Comfort food for the soul: Berikan posisi yang nyaman, ciptakan lingkungan yang bersih, nyaman dan tenang, anjurkan orangtua untuk menghubungi perawat jika membutuhkan sesuatu, berikan pujian untuk setiap upaya yang dilakukan orangtua, panggil anak dengan namanya.

Evaluasi dilakukan pada perawatan hari ke lima. Hasil evaluasi keperawatan yaitu: 1) Fisik, pada tipe kenyaman relief, frekuensi napas $48 \mathrm{x} / \mathrm{mnt}$, dengan O2 Nasal Kanule 1/2 Liter/menit, suhu $38^{\circ} \mathrm{C}$, turgor kulit tidak elastis, masih terdapat ronchi, diare bab 2 kali, konsistensi cair ada ampas, wana kuning. Tanggal 20 Maret 2017 pasien masih mengalami tipe kenyamanan relief yaitu: Conjungtiva anemis, melena 5-6 x/hari, turgor kulit tidak elastis, membran mukosa kering, tampak kemerahan pada area perianal skor 
SSDSS 2, suhu $39^{\circ} \mathrm{C}$. 2) Aspek psikospiritual, sosiokultural, dan lingkungan berada pada tipe kenyamanan transcendence.

\section{Pembahasan}

Terdapat tiga kasus kelolaan yang akan dibahas pada pembahasan ini. Tigakasus tersebut terdiri dari tiga kasus diare disertai penyakit penyerta lainnya. Pada kelima kasus ini anak mengalami kondisi diare dengan kerusakan integritas kulit yang berbeda, berdasarkan penilaian SSDDS.

Pembahasan aplikasi kenyamanan Kolcaba pada lima kasus kelolaan berdasarkan proses keperawtaan, yaitu: pengkajian, diagnosa keperawatan, intervensi keperawatan dan evaluasi. Uraian pembahasannya adalah sebagai berikut:

\section{Pengkajian}

Pengkajian pada teori Kenyamanan Kolcaba berdasarkan pada 4 aspek kenyamanan fisik, psikospiritual, sosiokultural, dan lingkungan (Chandra, Raman, Katharine, 2016). Pasien pada kasus keloaan ini berada pada rentang usia bayi sampai dengan usia balita, oleh karena itu saat melakukan pengkajian keperawatan anak lebih banyak menggunakan tehnik komunikasi non verbal sesuai dengan usia anak. Tehnik komunikasi non verbal yang digunakan seperti sentuhan, tersenyum dan kontak mata. Komunikasi verbal juga dilakukan dengan suara yang lembut.

Fokus pengkajian pada kerusakan integritas kulit yang dilakukan adalah pada area perianal. Aspek penilaian menggunakan SSDDS, dengan 4 aspek yang dikaji yaitu, adanya eritema dan iriasi, luasnya diaper dermatitis, papula dan pustula, dan keutuhan kulit (Buckley et al, 2016). Pengkajian pada kelima kasus berfokus pada integritas kulit yang berada pada aspek fisik, hanya tingkat kenyaman pada tiap-tiap kasus berbeda. Hasil pengkajian kerusakan integritas kulit pada kelima kasus kelolaan dilakukan dengan menggunakan SSDDS berada pada rentang skor 0-6.

Pengkajian kondisi kulit perianal pada tiga kasus terpilih menunjukkan hasil bahwa telah terjadi masalah kerusakan integritas kulit yang aktual, yang ditandai dengan adanya kemerahan yang tampak pada area perianal.

Integritas kulit dapat dipengaruhi oleh faktor instrinsik dan ekstrinsik. Kondisikondisi seperti berikut ini merupakan faktor insrinsik yang dapat memengaruhi integritas kulit, yaitu adanya edema, hipotermia, dehidrasi, sepsis, obat-obatan, imobilitas, anemia, inkontinensia, penurunan berat badan dan kuran gizi. Sedangkan yang menjadi faktor ekstrinsik diantaranya adalah tekanan, gesekan, dan kelembaban (Fergusson, 2008; Kozier et al, 2010).

Skor SSDDS pada ketiga kasus diatas berbeda. Kasus yang pertama memiliki skor SSDDS yang tinggi (6) yang artinya kondisi kerusakan integritas kulit yang dialami merupakan yang paling buruk. Hal ini dapat disebabkan pasien tidak hanya terdiagnosis diare tetapi pasien juga terdiagnosis morbili. Virus morbili merupakan virus yang hidup di mukus hidung dan tenggorokan penderita yang dapat menyebar keberbagai organ melalui hematogen. Penyebaran virus ini akan menimbulkan reaksi radang. Reaksi peradangan yang timbul pada kulit menyebabkan hiperplasia kelenjar limfoid. Bila penyebaran terjadi pada kulit, maka kulit sekitar sebasea dan folikel rambut pembengkakan dan timbul eritema yang membentuk makula dan papula pada kulit. Hal ini akan tersng berlanjut sampai muncul rash dan ruam pada seluruh tubuh dan deskuamasi rasa gatal. Morbili merupakan penyakit infeksi akut yang ditandai dengan tiga stadium yaitu stadium prodromal, eksantematosa dan konvalesen (Hockenberry \& Wilson, 2013). Pasien kasus kelolaan pertama, pasien berada pada stasium eksantematosa. Pada stadium ini terjadi 
ruam atau eritema yang berbentuk makula-papula disertai peningkatan suhu tubuh. Hal yang yang menyebabkan kondisi kerusakan integritas kulit pada kasus pertama berat.

Pada pasien kelolaan kedua pasien mengalami kerusakan integritas kulit dengan skor SSDDS yaitu empat, dimana pada area kulit perianal temukan eritema dan iritasi dengan skor 4 dan telah terjadi kerusakan integritas kulit pada area yang lebih dalam sampai pada lapisan dermis kulit. Hal ini dapat dipengaruhi oleh diagnosis medis pasien yaitu atresia billier. Atresia bilier terjadi karena proses inflamasi berkepanjangan yang menyebabkan kerusakan progresif pada duktus bilier ekstrahepatik sehingga menyebabkan hambatan aliran empedu. Jadi, atresia bilier adalah tidak adanya atau kecilnya lumen pada sebagian atau keseluruhan traktus bilier ekstrahepatik yang menyebabkan hambatan aliran empedu. Akibatnya di dalam hati dan darah terjadi penumpukan garam empedu dan peningkatan bilirubin direk yang menyebabkan rasa gatal (Kyle, T \& Carman, 2013).

Pada pasien kelolaan ketiga pasien mengalami kerusakan integritas kulit dengan skor SSDDS 2, dimana pada area perianal hanya ditemukan iritasi kulit jelas

Pada pengkajian berdasarkan kenyamanan Kolcaba, untuk aspek psikospiritual, sosiokultural, dan lingkungan residen mendapatkan data dari orang tua. Ketiga kasus kelolaan belum mampu berkomunikasi, dan dibutuhkan pengamatan terhadap perilaku anak untuk mendapatkan data kenyamanan terkait aspek psikospiritual, sosiokultural, dan lingkungan, sehingga pada ketiga aspek ini residen mendapatkan data berdasarkan komunikasi dengan orangtua. Namun dalam paradigma keperawatan anak, anak merupakan individu yang masih bergantung pada lingkungan untuk memenuhi kebutuhan individu dalam hal ini adalah keluarga. Oleh karena itu, penerapan asuhan keperawatan berfokus pada keluarga (family-centered care). Family-Centered Care merupakan pendekatan yang holistik, yang tidak hanya memfokuskan asuhan keperawatan kepada anak sebagai pasien atau individu dengan kebutuhan biologis, psikologis, sosial dan spiritual tetapi juga melibatkan keluarga sebagai bagian yang konstan dan tidak dapat dipisahkan dari kehidupan anak (Wong et al, 2009).

\section{Diagnosa Keperawatan}

Masalah kerusakan integritas kulit pada area perianal pada anak dengan diare merupakan masalah yang kurang mendapatkan perhatian, karena orang tua cenderung tidak menyampaikan masalah yang terjadi pada anaknya. Selama ini perawat dalam melakukan pengkajian lebih berfokus pada pengkajian yang dapat dilihat secara langsung, sehingga pengkajian pada area diaper sering terlewatkan. Pengkajian pada area diaper lebih sering berdasarkan wawancara kepada orangtua tanpa melihat secara langsung kondisi area perianal. Perawat mengetahui terjadi kerusakan integritas kulit saat orangtua meminta terapi untuk megobati area perianal, padahal kerusakan integritas kulit dapat dicegah jika diberikan intervensi sejak dini.

Kerusakan integritas kulit adalah perubahan atau gangguan epidermis atau dermis. Batasan karakeristik untuk menegakkan diagnosis keperawatan ini adalah adanya kerusakan pada lapisan kulit (dermis), kerusakan permukaan kulit (epidermis), dan invasi struktur kulit (Herdman, 2012; Wilkinson, 2012).

\section{Intervensi dan Implementasi Keperawatan}

Teori Kenyamanan Kolcaba dapat digunakan untuk memberikan intervensi kenyamanan bagi pasien. Teori ini secara integratif bertujuan memenuhi 
kebutuhan kenyamanan secara holistik. Teori Kenyamanan Kolcaba bersifat integratif yang merupakan pendekatan dengan menggabungkan beberapa metode yang bertujuan untuk memberikan kenyamanan pada empat konteks kenyamanan: Fisik, psiko spiritual, sosial budaya, dan lingkungan (Chandra, Raman, Katharine, 2016).

Intervensi dalam Kolcaba terbagi atas tiga kategori yaitu standard of comfort, coaching dan comfort food for the soul. Ketiga kategori intervensi ini dapat digunakan dalam mengatasi masalah ketidaknyamanan di empat konteks kenyaman yang muncul pada pasien. Keberhasilan pelaksanaan intervensi untuk mengatasi masalah sangat dipengaruhi oleh faktor-faktor diluar teori keperawatan, seperti ketersediaan sarana prasarana, kemampuan keluarga untuk berpartisipasi dalam perawatan anak. Namun hal ini dapat diatasi dengan kreatifitas dan inovasi perawat untuk mengatasi segala keterbatasan yang ada. Dalam menerapkan intervensi perianal care diperlukan beberapa peralatan untuk tempat air bersih, tidak semua rumah sakit menyediakan tetapi hal ini dapat dimodifikasi dengan meminta keluarga menyediakan peralatan yang sederhana seperti botol tempat air mineral. Selain ini perawat diharapkan selalu memotivasi keluarga untuk melakukan perianal care.

Intervensi keperawatan coaching adalah intervensi yang bertujuan untuk mengurangi kecemasan, memberikan informasi, menanamkan harapan, dan membantu merencanakan pemulihan. Implementasi yang dilakukan adalah Mengajarkan keluarga membersihkan area perianal dengan konsep $\mathrm{ABCDE}$ $(\mathrm{A}=$ Air,$\quad \mathrm{B}=$ Barrier,$\quad \mathrm{C}=$ Clenasing, $\mathrm{D}=$ Diaper, $\quad E=$ Education $), \quad$ dan memberikan dukungan informasi tentang perawatan perianal. Membersihkan area perianal dengan konsep ABCDE merupakan salah satu upaya yang dapat dilakukan secara mandiri oleh perawat untuk mencegah dan mengurangi kejadian diaper dermatitis. Konsep ABCDE ini adalah mengajarkan kepada keluarga untuk memaksimalkan waktu bebas diaper, memberikan perlindungan dengan menggunakan krim pelindung kulit setiap penggantian diaper, membersihkan area diaper dengan lembut menggunakan air dan kain lembut dan menghindari menggosok kulit dengan keras, menggunakan popok yang menyerap air, menggunakan diaper yang menyerap, mengganti diaper segera setelah diaper kotor, setidaknya setiap 1 sampai 3 jam di siang hari dan sekali di malam hari, dan mengajarkan orang tua tentang cara menjaga kebersihan area diaper (Shin, 2014).

Implementasi keperawatan comfort food for the soul yang dilakukan adalah memanggil pasien dengan namanya, dan menganjurkan keluarga untuk menghubungi perawat jika membutuhkan sesuatu. Intervensi comfort food for the soul yaitu intervensi dengan menawarkan sesuatu yang menyenangkan untuk membuat anak dan keluarga merasa lebih diperhatikan dan lebih merasa dikuatkan.

\section{Evaluasi Keperawatan}

Katharine Kolcaba mendefinisikan keperawatan sebagai proses untuk menilai kebutuhan kenyamanan pasien, mengembangkan dan menerapkan intervensi keperawatan yang tepat dan mengevaluasi kenyamanan pasien setelah diberikan intervensi keperawatan. Tujuan akhir dari keperawatan adalah untuk meningkatkan kenyamanan kepada pasien. Dengan melakukan penilaian kembali terhadap tingkat kenyamanan pasien, perawat dapat mengevaluasi keberhasilan dari intervensi yang telah dilakukan (Chandra, Raman, \& Katharine, 2016).

Evaluasi keperawatan merupakan tahap akhir dalam proses keperawatan yang dilakukan untuk menilai efektifitas intervensi keperawatan yang telah 
dilakukan berdasarkan tujuan yang telah ditetapkan. Evaluasi untuk masalah keperawatan kerusakan integritas kulit pada kasus pertama setelah tiga hari perawatan integritas kulit masih menunjukkan tipe kenyamanan relief. Penurunan skor SSDSS kurang bermakna dari enam turun menjadi lima dengan berkurangnya kemerahan pada area perianal. Pasien sudah tidak mengalami diare dan rash pada seluruh tubuh mulai berwarna kecoklatan. Pada hari evaluasi pasien sudah diijinkan pulang.

Pasien kelolaan kedua dengan diare dan atresia billier, setelah perawatan hari keempat. integritas kulit berada pada tipe kenyaman ease ditandai dengan penurunan skor SSDSS dari empat menjadi dua dimana masih terdapat kemerahan ringan pada area perianal. Pasien diijinkan pulang pada hari keperawatan ketujuh.

Pasien kelolaan ketiga dengan diare dan HIV-AIDS, setelah perawatan hari ketiga, integritas kulit berada pada tipe kenyaman transendence. Skor SSDSS menurun dari dua menjadi nol.

Teori kenyaman Kolcaba dapat diaplikasikan pada hampir semua aspek dalam proses keperawatan mulai dari pengkajian sampai evaluasi. Pengkajiam dengan menggunakan teori kenyamanan Kolcaba dapat digunakan untuk menggali semua data dari pasien secara komprehensif mulai dari konteks fisik, psikospiritual, lingkungan, dan sosial budaya.

Berdasarkan hasil evaluasi keperawatan tidak semua masalah integritas kulit dapat teratasi saat pasien diijinkan pulang. Masalah integritas kulit yang tidak teratasi disebabkan karena kondisi penyakit penyerta lain yang berhubungan dengan integritas kulit yaitu rash yang terjadi pada pasien dengan morbili dan adanya atresia billier yang menyebabkan rasa gatal dikulit. Hal ini menunjukkan bahwa teori keperawatan Kenyamanan Kolcaba dapat memberikan keberhasilan dalam memberikan asuhan keperawatan pada pasien. Banyak faktor lain yang memengaruhi keberhasilan asuhan keperawatan seperti adanya kerjasama disiplin ilmu yang lain, pengembangan intervensi yang berdasarkan evidence based practice nursing sebagai upaya agar pasien terpenuhi kenyamanan selama pemberian asuhan keperawatan.

Kendala yang dihadapi adalah ketika melakukan analisis dari hasil pengkajian pada empat konteks kenyaman untuk diklasifikasikan kedalam tiga tipe kenyaman dari teori kenyaman Kolcaba yaitu relief, ease, dan transcendence karena tidak ada standar baku yang jelas dari masing-masing kategori.

\section{Simpulan dan Saran}

Pemberian asuhan keperawatan bedasarkan teori kenyamanan Kolcaba pada ketiga pasien kelolaan dengan kerusakan integritas kulit secara umum dapat diterapkan dengan baik. Memberikan rasa nyaman kepada pasien membantu proses penyembuhan pasien. Kerusakan integritas kulit merupakan salah satu faktor yang menyebabkan ketidaknyamanan pasien. Pemberian intervensi keperawatan mandiri seperti perawatan perianal dan mengatasi dan mencegah terjadinya diaper dermatitis pada pasien. Hal ini tidak terlepas dari adanya keterlibatan orang tua dalam melakukan tindakan keperawatan. Teori kenyamanan Kolcaba merupakan salah satu teori yang mudah diaplikasikan pada praktik keperawatan, diharapkan perawat sebagai pemberi asuhan dapat meneruskan praktik aplikasi teori yang disesuaikan dengan karakteristik ruangan agar pengembangan profesi dapat diteruskan.

\section{Daftar Pustaka}

Buckley, B.S., Mantaring, B.J., Dolitas, R.B., Lapitan, M.C., \& Monteagudo, A. (2016). A new scale for assessing the severity of uncomplicated diaper dermatitis in 
infants: Development and validation. Pediatric Dermatology 33 (6), 632-639. doi: $10.1111 /$ pde. 12988

Chandra, S.N., Raman, K., \& Katharine, K. (2013). Application of Katharine Kolcaba Comfort Theory in post operative child: Delivering integrataive comfort care intervention by using-Theory of Comfort-A Case Study of a 5 year old child admitted in PICU with laparotomy experiencing post operative discomfort. International Journal of Science and Research (IJSR). 5 (6). doi: 1021275

Herdman, T.H. \& Kamitsuru, S. (2014). NANDA International nursing diagnoses: Definition \& clasification, 2015-2017. Oxford: W'ley Blackwell

Hockenberry, M. J., \& Wilson, D. (2013). Wong's essentials of pediatric nursing (9th Ed.). St. Louis, MO: Mosby Elsevier

Kolcaba, K. (2005). Comfort Theory and Its Application to Pediatric Nursing. Retrieved from: http://medscape.com/viewarticle/50 7387_2

Kozier, B., Erb, G., Berman, A., \& Snyder, S.J. (2010). Buku ajar fundamental keperawatan: konsep, proses, dan praktik Ed 7 volume 2. Alih Bahasa, Andry Hartono, Sari Kurnianingsih, Setiawan, Jakarta: EGC

Marcdante, K.J., Kliegman, R.M., Jenson, H.B., \& Behrman, R.E. (2010). Nelson ilmu kesehatan anak. Edisi keenam. Alihb ahasa: IDAI. Singapore: Elsevier

Potts, N.L \& Mandleco, B.L. ( 2012). Pediatric nursing caring for children and their families. USA : Nelson Education
Ravanfar, P., Wallace, J.S, \& Pace, N.C. (2012). Diaper dermatitis: A review and update. Current Opinion in Pediatrics, 24(4), 472-479. doi: 10.1097

Shin, H.T. (2014). Diagnosis and management of diaper dermatitis. Pediatr Clin $N$ am 61, 367-382. doi: 10.1016/j.pcl.2013.11.009

Wilkinson, J.M., \& Ahern, N.R. (2012). Buku saku diagnosis keperawatan: diagnosis NANDA, intervensi NIC, kriteria hasil NOC. Ed 9. Alih bahasa, Esty Wahyuningsih. Jakarta: EGC

Wong, D. L., Hockenberry-Eaton, M., Wilson, D., Winkelstein, M. L., \& Schwartz, P. (2008). Buku ajar: Keperawatan pediatrik. (Edisi 6). Jakarta: EGC. 